\title{
Manganese in RR Cotton as Affected by Glyphosate
}

\section{João Paulo Gonsiorkiewicz Rigon, Silvia Capuani, Jayme Ferrari Neto \& Ciro} Antonio Rosolem

To cite this article: João Paulo Gonsiorkiewicz Rigon, Silvia Capuani, Jayme Ferrari Neto \& Ciro Antonio Rosolem (2017) Manganese in RR Cotton as Affected by Glyphosate, Communications in Soil Science and Plant Analysis, 48:16, 1955-1962, DOI: 10.1080/00103624.2017.1407783

To link to this article: https://doi.org/10.1080/00103624.2017.1407783

曲 Published online: 04 Dec 2017.

Submit your article to this journal $₫$

Џll Article views: 38

View Crossmark data \lceil 


\title{
Manganese in RR Cotton as Affected by Glyphosate
}

\author{
João Paulo Gonsiorkiewicz Rigon, Silvia Capuani (D), Jayme Ferrari Neto, \\ and Ciro Antonio Rosolem
} Department of Crop Science, College of Agricultural Sciences, São Paulo State University (UNESP), Botucatu, São
Paulo, Brazil

\begin{abstract}
There is evidence that glyphosate application in soybean tolerant to herbicides could interfere in the manganese $(\mathrm{Mn})$ nutrition of the crop, but there is no information on this effect in cotton plants. This study aimed at assessing manganese accumulation and distribution in cotton as affected by glyphosate application. The experiment was conducted in nutrient solution with four Mn concentrations and two cotton cultivars: conventional NuOpal and NuOpal tolerant to glyphosate (RR). Glyphosate was applied or not to the tolerant cultivar. The inclusion of the glyphosate resistance gene in cotton and herbicide, application increased shikimic acid (ShA) concentration in the plants. Glyphosate application decreased cotton leaf area and the dry matter production of the plant structures. The adverse effects of glyphosate were not overcome with higher $\mathrm{Mn}$ rates in the solution.
\end{abstract}

\section{ARTICLE HISTORY}

Received 15 July 2016

Accepted 19 September 2017

\section{KEYWORDS}

Dry matter; Gossypium

hirsutum; Mn uptake;

shikimic acid

\section{Introduction}

The herbicide glyphosate [N-(phosphonomethyl) glycine)] is widely used in agriculture due to its broad spectrum of action and low environmental risk. This herbicide acts by blocking the shikimic acid (ShA) pathway, the main route of aromatic amino acids production, which accumulate in plant tissues (Shieh, Geiger, and Serviates 1991), as observed in tolerant to glyphosate (RR) corn hybrids (Reddy, Bellaloui, and Zablotowicz 2010), canola (Petersen et al. 2007), and sunflower (Eker et al. 2006). There are, moreover, reports of physiological alterations in non-target plants subjected to the herbicide, with changes in the uptake, transport, and accumulation of Mn (Römheld et al. 2005).

Some researchers reported that even plants that have been genetically modified for resistance to the RR could be less efficient in the accumulation of Mn due to the accumulation of ShA in plant tissue, suggesting the need for supplemental fertilization with $\mathrm{Mn}$, mainly in soybean crop (Gordon 2007; Zobiole et al. 2010a) although studies have been unable to agree on such changes (Andrade and Rosolem 2011; Basso et al. 2011).

The supposed lower efficiency in the uptake of Mn by RR soybean and corn plants would be a consequence of the modifications in the rhizosphere environment, with an increase in root exudation of compounds that increase the population of oxidizing microorganisms. These compounds are toxic to Mn-reducing microorganisms in the soil, what would make Mn practically unavailable to plants (Johal and Huber 2009; Ozturk et al. 2008). There is also the possibility of chelation between secondary compounds of the herbicide and $\mathrm{Mn}$ in the plant meristems (Feng, Chiu, and Sammons 2003). Yellowing of the upper leaves of RR soybean has been observed after the application of glyphosate as a result of a decrease in chlorophyll content caused by the herbicide (Basso et al. 2011;

CONTACT João Paulo Gonsiorkiewicz Rigon @ jprigon@fca.unesp.br @ Department of Crop Science, College of Agricultural Sciences, São Paulo State University (UNESP), Botucatu, São Paulo, Brazil.

Color versions of one or more of the figures in the article can be found online at www.tandfonline.com/lcss. 
Johal and Huber 2009), a symptom that is similar to Mn deficiency (Andrade and Rosolem 2011) and known as "yellow flashing".

In addition to $\mathrm{Mn}$, in general, the nutritional state of RR soybean may be affected by the use of glyphosate (Zobiole et al. 2010a). The authors observed that non-modified parental lines contained higher concentrations of macro and micronutrients, as well as higher physiological activity and functional chlorophyll in the absence of the herbicide when compared with RR plants.

With the introduction of cotton cultivars tolerant to glyphosate in Brazil, the use of this herbicide is growing because of its advantages for weed management. With the hypothesis that RR plants are less efficient in Mn uptake and redistribution, this genetic modification along with glyphosate application in cotton could induce $\mathrm{Mn}$ deficiency, requiring supplementation through fertilization to meet plant's requirements. This study aimed at assessing the accumulation and distribution of $\mathrm{Mn}$, as well as the concentration of ShA in RR cotton as affected by glyphosate application.

\section{Materials and methods}

The study was conducted in Botucatu, SP, Brazil, under greenhouse conditions. The treatments consisted of four concentrations of $\mathrm{Mn}$ in the nutrient solution and two cotton genotypes (conventional NuOpal and glyphosate resistant NuOpal RR ). The genotype Nuopal was grown without the application of the herbicide and the genotype $\mathrm{NuOpal} \mathrm{RR}^{\circ}$ was grown with and without glyphosate application. The experimental design was a $4 \times 3$ factorial arrangement in randomized complete blocks with four replications.

Cotton seeds previously treated with fungicide were placed to germinate in a germination chamber at $25^{\circ} \mathrm{C}$. After 6 days, two seedlings were transferred to each plastic pot with $4 \mathrm{~L}$ of nutrient solution (Hoagland and Arnon 1950). In the first week, a solution diluted to $1 / 3$ strength was used and, in the second week, the solution was diluted to $1 / 2$ strength, for adaptation of the seedlings. From the third week onwards, a solution at full concentration was used and changed every week after that. The nutrient solution was modified with concentrations of $\mathrm{Mn}^{2+}\left(0.0,0.25,0.5\right.$, and $\left.1.0 \mathrm{mg} \mathrm{L}^{-1}\right)$. The nutrient solution was purified by passing through an anion exchange resin column (Dowex $1 \times 8-10$, 100-200 mesh, Sigma, USA). The $\mathrm{pH}$ of the solution was monitored daily and kept at values close to 5.8 by the addition of $0.1 \mathrm{~N}$ of $\mathrm{HCl}$ or $\mathrm{NaOH}$. The temperature in the greenhouse was controlled and kept between 20 and $32^{\circ} \mathrm{C}$.

In the treatment with glyphosate, it was applied the equivalent of $720 \mathrm{~g} \mathrm{ha}^{-1}$ (acid equivalent) using a product formulated with isopropylamine salt base, when the plants were in the V4 stage (Marur and Ruano 2001), 24 days after emergence (DAE). For spraying, the plants were removed from the greenhouse, and the application was performed using a pressurized backpack sprayer $\left(\mathrm{CO}_{2}\right)$ equipped with a spray nozzle (DG TEEJET 110-02) with a mixture spray volume of $200 \mathrm{~L} \mathrm{ha}^{-1}$. Two hours after glyphosate application, plants were returned to the greenhouse. At the B1 stage (Marur and Ruano 2001), at $45 \mathrm{DAE}$, the plants were collected and separated into shoots (stems and branches), roots, and leaves. Leaf area was determined by a scanner LI-3100C LI-COR ${ }^{\circ}$. The samples were subsequently dried in a forced air oven at $60^{\circ} \mathrm{C}$ for $72 \mathrm{~h}$ and dry matter weight was determined. The material was ground in a Wiley-type mill, and part of the leaf samples were subjected to extraction for the determination of shikimic acid. The Mn concentration was determined in the other part or the samples by digestion in a nitro-perchloric acid solution and reading in an atomic absorption spectrophotometer.

For the evaluation of shikimic acid, $200 \mathrm{mg}$ of dry leaf samples were placed in $15 \mathrm{~mL}$ Falcon-type tubes with the addition of $10 \mathrm{~mL}$ of methanol and water (1:1). The tubes were subjected to an ultrasonic bath with an ultrasonic frequency of $42 \mathrm{KHz}$ for $30 \mathrm{~min}$ (Matallo et al. 2009). The samples were then centrifuged at $4,000 \mathrm{rpm}(2,150 \mathrm{~g})$ at $20^{\circ} \mathrm{C}$ for $10 \mathrm{~min}$ (Rotanta $460 \mathrm{R}^{\circ}$ centrifuge). The supernatant solution was filtered in a Millex HV (Millipore) $0.45 \mu \mathrm{m}$ filter, with a $13 \mathrm{~mm}$ Durapore membrane, and placed in a $9 \mathrm{~mm}$ amber glass vial (Flow Supply) with $2 \mathrm{~mL}$ capacity for later 
quantification by High Performance Liquid Chromatography (HPLC) (Shimadzu Proeminence UFLC model) and the 3200 Q TRAPmet ${ }^{\oplus}$ mass spectrometer (Applied Biosystems).

The data were subjected to ANOVA, and the mean values of the cultivars were compared by the paired $t$-test (LSD, $p<0.05$ ). Response curves were fitted for the Mn concentrations.

\section{Results}

Manganese concentration in cotton roots increased with the nutrient solution $\mathrm{Mn}$ rates, and when glyphosate was applied it was higher in the RR cotton than in conventional (20\%) and RR cotton (48\%) without herbicide with the highest level of $\mathrm{Mn}$ in the solution (Figure 1). In the leaves and steams, it was observed only the effect of solution Mn levels (Figure 1).

The accumulation of $\mathrm{Mn}$ in cotton plants increased with the increases in Mn concentrations in the nutrient solution (Figure 2). However, the application of glyphosate interacted with the solution $\mathrm{Mn}$, resulting in a lower accumulation of the nutrient in cotton leaves and stems, particularly in the highest $\mathrm{Mn}$ concentration in solution (Figure $2 \mathrm{~B}$ and $\mathrm{C}$ ). This interaction resulted in a $35 \%$ decrease in $\mathrm{Mn}$ accumulation in leaves of the transgenic cultivar + glyphosate, as well as from $50 \%$ to $70 \%$ lower $\mathrm{Mn}$ accumulation in the stem, as compared with plants without herbicide and grown at rates of 0.25 and $1.0 \mathrm{mg} \mathrm{L}^{-1}$ of solution $\mathrm{Mn}$, respectively.

The inclusion of the glyphosate resistance gene in cotton did not affect dry matter production, but herbicide application considerably decreased dry matter weight of all the plant structures, similar to how glyphosate decreased the leaf area in this cultivar (Figure 3). It was observed an interaction of $\mathrm{Mn}$ rates applied and cultivars in all the values of the plant structures and leaf area.
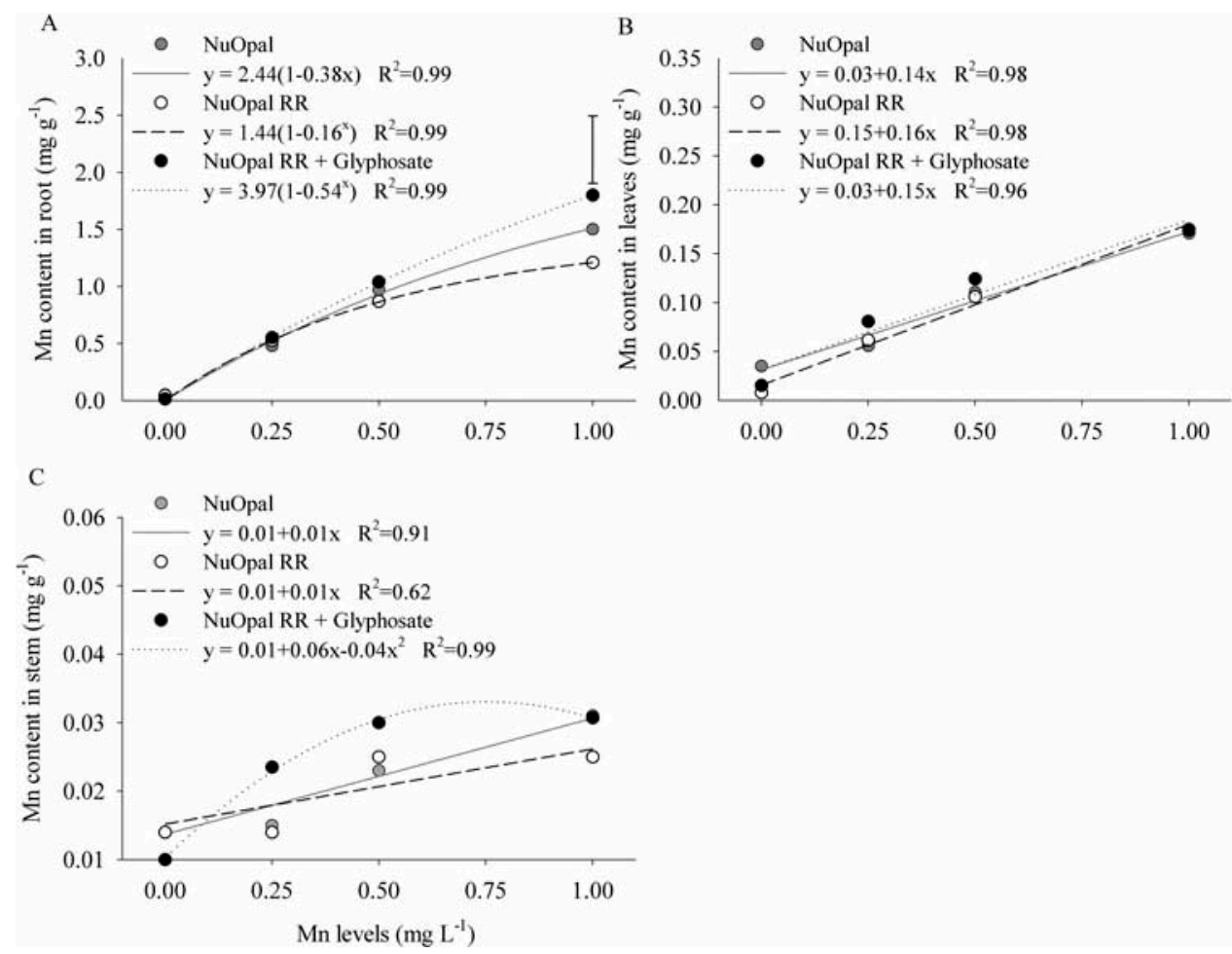

Figure 1. Mn content in roots (A), leaves (B), and stems (C) of cotton of the conventional and transgenic NuOpal cultivars, with and without the application of glyphosate, as a function of Mn levels in the nutrient solution. Vertical bars represent the value of LSD to the t-test at $p<0.05$. 
A
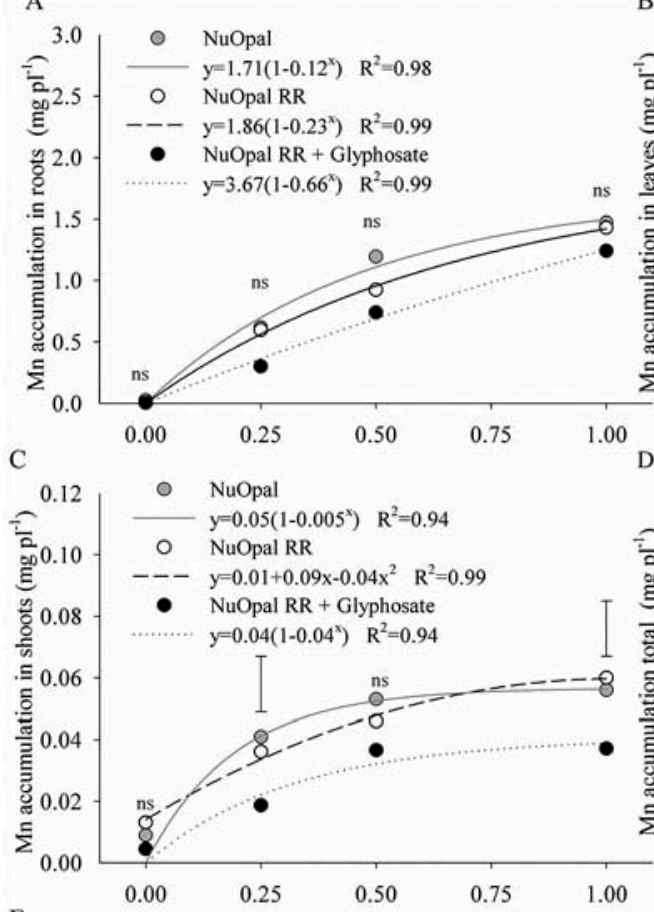

E

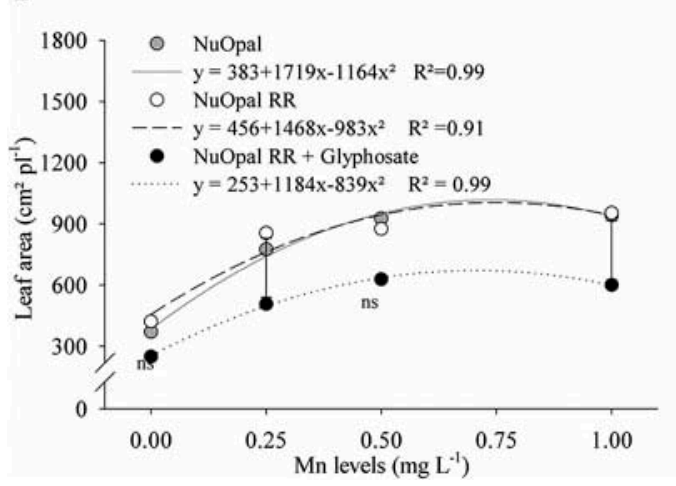

B

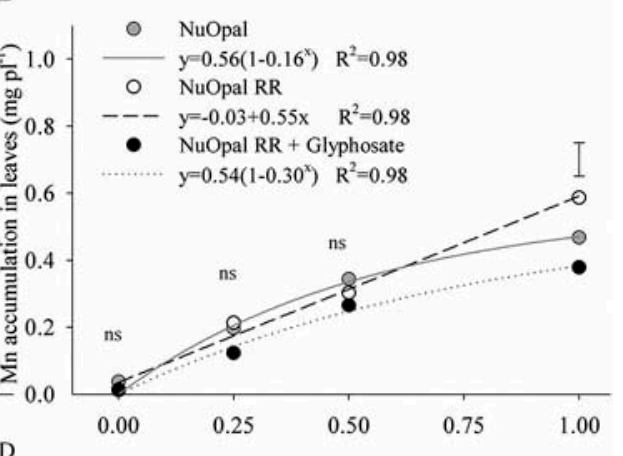

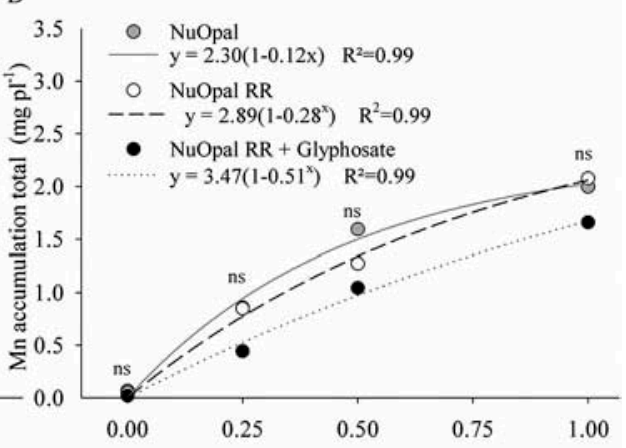

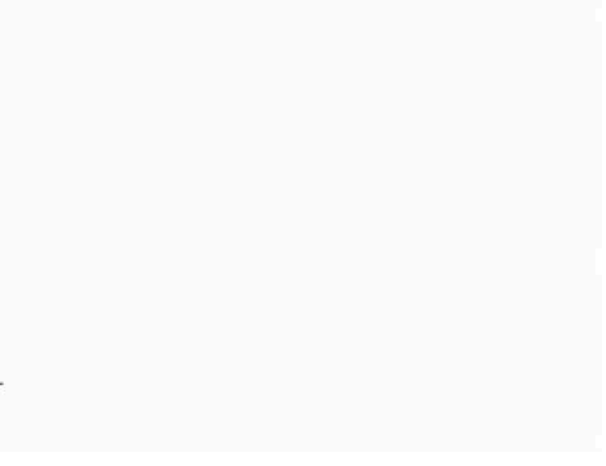

Figure 2. Mn accumulation in roots (A), leaves (B), stems (C), total (D) and leaf area (E) of cotton of the conventional and transgenic NuOpal cultivars, with and without the application of glyphosate, as a function of $\mathrm{Mn}$ levels in the nutrient solution. Vertical bars represent the value of LSD to the t-test at $p<0.05$.

Dry matter yields (DMY) of the conventional and transgenic cultivars without glyphosate application showed a quadratic response to solution $\mathrm{Mn}$, while the reaction of the transgenic cultivar with glyphosate application was linear. With $0.25,0.5$, and $1.0 \mathrm{mg} \mathrm{L}^{-1}$ of $\mathrm{Mn}$ in solution, the root DMY of the conventional and transgenic cultivars in the absence of herbicide, were, respectively, 94 and 135, 79, and 67, 102 and 78\% higher than the values observed for the transgenic cultivar with glyphosate. The results were similar for the other plant structures and the total DMY.

It is important to highlight that the decrease of DMY in transgenic cotton with glyphosate application was significant, with the values of DMY being equal with the application of 0.5 and $1.0 \mathrm{mg} \mathrm{L}^{-1}$ of $\mathrm{Mn}$. Therefore, there is no response for this cultivar to the highest rate of $\mathrm{Mn}$ applied.

The Mn rates in the solution did not affect the concentration of shikimic acid in cotton leaves, which was $44 \%$ greater in NuOpal RR + Glyphosate than in the conventional cultivar (Figure 4). 
A

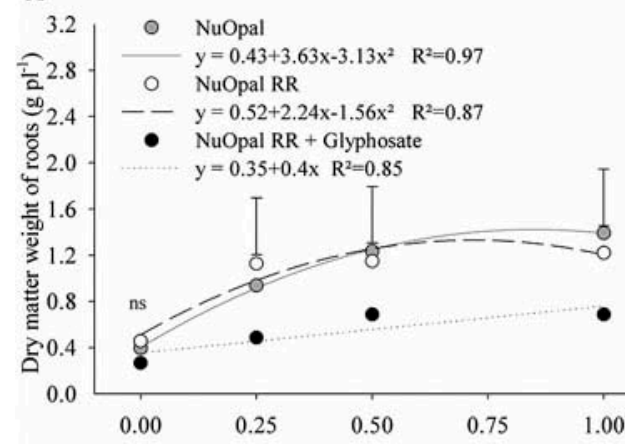

B

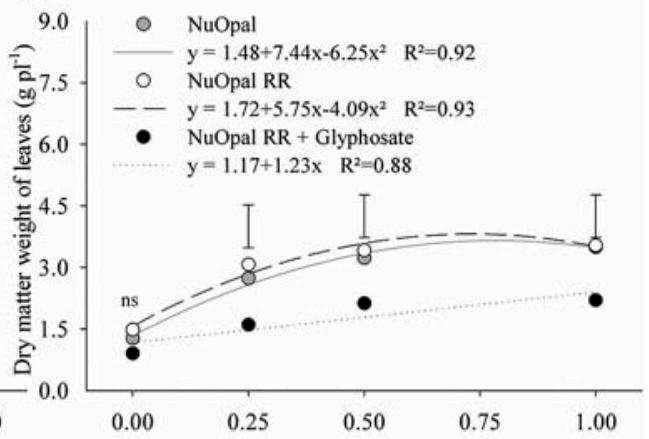

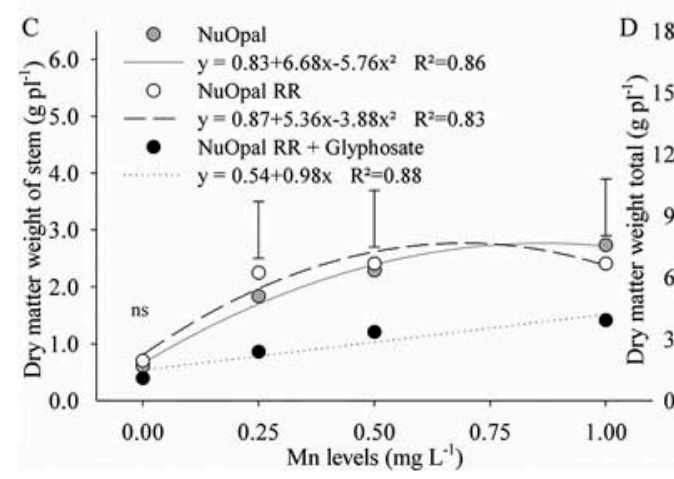

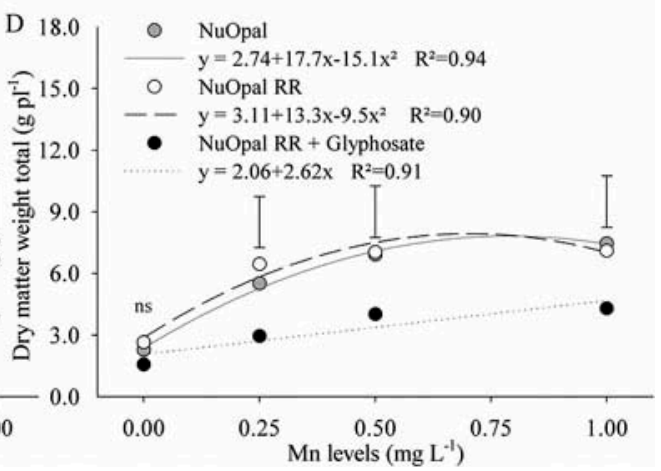

Figure 3. Dry matter weight of roots (A), leaves (B), stems (C), and total (D), and leaf area (E) of cotton of the conventional and transgenic NuOpal cultivars, with and without application of glyphosate, as a function of $\mathrm{Mn}$ levels in the nutrient solution. Vertical bars represent the LSD value to the t-test at $\mathrm{p}<0.05$.

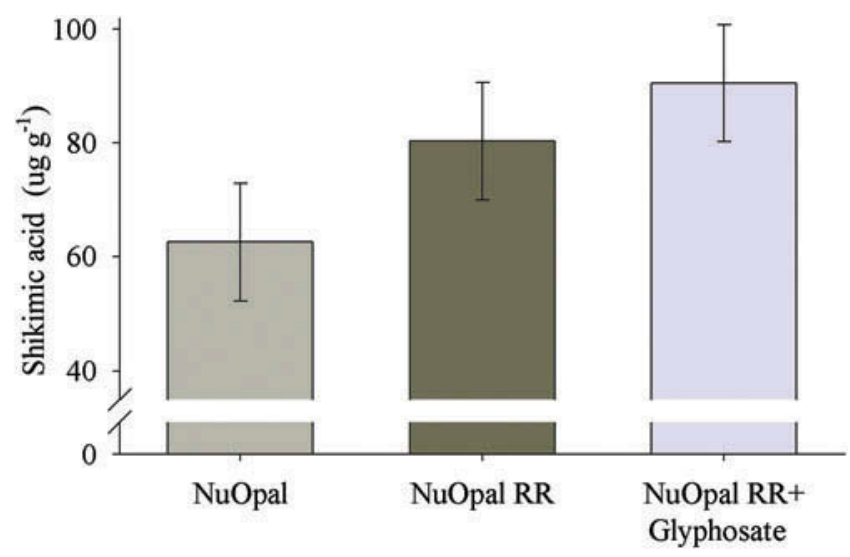

Figure 4. Accumulation of shikimic acid in leaves of cotton of the conventional and transgenic NuOpal cultivars with and without application of glyphosate. Vertical bars represent the LSD value to the t-test at $p<0.05$.

\section{Discussion}

The greater Mn content in the roots of the transgenic cultivar with the application of glyphosate could indicate that the application of the herbicide resulted in greater uptake of the micronutrient by cotton. However, cationic nutrients easily bind to the glyphosate molecule, forming compounds of limited solubility and stability, known as chelates (Cakmak et al. 2009). Hence, it may 
have occurred $\mathrm{Mn}$ chelation at the higher glyphosate application rate, thus impeding the translocation of the micronutrient to other parts of the plant (Bott et al. 2008; Eker et al. 2006). Decreased Mn content in the cotton stems with the application of glyphosate (Figure 1C) indicates that the translocation of the micronutrient was impeded at the greater application rate, although the stem exhibited lower Mn content than other plant structures. This effect might have been more pronounced if the experiment had also included the reproductive period, the stage at which a higher uptake of $\mathrm{Mn}$ by the cotton plant is observed (Rosolem and Ferelli 2000). Eker et al. (2006) in a study with sunflower, concluded that glyphosate impedes the uptake, transport, and accumulation of $\mathrm{Fe}$ and $\mathrm{Mn}$ due to the formation of insoluble compounds of the herbicide with the cationic micronutrients. Nevertheless, according to Duke et al. (2012), although a significant fraction of the minerals in the plant tissue is chelated by the herbicide, this is unlikely to have a substantial effect on mineral nutrition. The negative effects of glyphosate on plant mineral nutrition varied depending on their growth stages, with younger plants being more sensitive than plants receiving glyphosate at a later growth stage (Zobiole et al. 2010a)

In relation to the lower accumulations of $\mathrm{Mn}$ associated with the application of glyphosate in $\mathrm{RR}$ cotton, it may be inferred that this was not a direct effect of the inclusion of the resistance gene in cotton, because the inclusion of the glyphosate resistance gene does not inhibit cotton development, but may be attributed to the effects of the herbicide. Thus, even when the highest rate of $\mathrm{Mn}\left(1.0 \mathrm{mg} \mathrm{L}^{-1}\right)$ was applied in the RR cultivar, which received the glyphosate application, it accumulated the same amount of Mn in the roots, leaves, and in all the plant as the conventional cultivar at half of the highest application rate $\left(0.5 \mathrm{mg} \mathrm{L}^{-1}\right)$ (Figure 2). This, along with the lack of response to the maximum rate of $\mathrm{Mn}$, highlights inefficiency in the accumulation of $\mathrm{Mn}$ in transgenic cotton with the application of glyphosate. So the Mn applications does not compensate the negative effects of glyphosate.

Also in a study with nutrient solution and the same rate of glyphosate $\left(720 \mathrm{~g} \mathrm{ha}^{-1}\right.$ a.e. $)$ of the present study, Neumann et al. (2006), observed that the herbicide impeded the accumulation of Mn in RR soybean. Similar results were reported by Gordon (2007) in a study with soybean when the authors indicated that the introgression of the glyphosate resistance gene in soybean led to Mn not being accumulated in the same way as in conventional cultivars.

One potential reason for the decrease observed in cotton growth with the application of glyphosate is a possible toxicity caused by the metabolite formed in the degradation of the herbicide aminomethylphosphonic acid (AMPA), which may cause damage to plants (Nandula et al. 2007; Zablotowicz and Reddy 2007). There is evidence of a reduction in the growth of the RR plant and the chlorophyll content due to this toxicity (Reddy, Rimando, and Duke 2004). Various studies confirm a decrease in growth and of the chlorophyll contents in RR soybean plants when subjected to glyphosate, as well as in the DMY of roots (Bott et al. 2008), shoots and leaves (Zobiole et al. 2010b). In a study using nutrient solution, it was observed that at an insufficient level of $\mathrm{Mn}$ in the solution, the reduction of root DMW did not occur, showing that the enzymatic conversion of glyphosate into AMPA in transgenic soybean requires a certain external level of Mn (Bott et al. 2008). Likewise, no effect of the cultivars was observed in cotton in the absence of $\mathrm{Mn}$, while increasing application rates of Mn negatively affected DMY, with the application of glyphosate, which may be attributed to the enzymatic conversion of glyphosate into AMPA in the presence of Mn. Metabolic studies with glyphosate in hydroponically-grown maize, wheat, cotton, and soya beans have shown the conversion of glyphosate to AMPA and further degradation in plant tissues (Fao 1997). Besides of that, the metabolism of $\left[{ }^{14} \mathrm{C}\right]$ glyphosate in tolerant soybean is similar of the cotton (Fao 2005). However, the amount of the degradation of glyphosate to AMPA in cotton is around 0.7-1.6\% (Fao 2005), but the underlying mechanisms are still unknown, which warrants further investigations.

The reduction in growth and leaf area of the transgenic cotton plants about a conventional cultivar may also be linked to the additive effects arising from the reduction of photosynthetic products. Zobiole et al. (2010a) observed a decrease in the photosynthetic rate, stomatal conductance, and transpiration rate in transgenic soybean with the application of glyphosate as compared with conventional soybean. According to the authors, the results may be explained by the damage 
caused by the chloroplasts or an indirect effect through immobilization of micronutrients essential to these organelles, such as $\mathrm{Mn}$ and $\mathrm{Zn}$.

The high concentrations of shikimic acid corroborate the results observed by Pline et al. (2002), who studied the accumulation of this metabolite in both glyphosate-sensitive and -resistant cotton cultivars, and also found an increase in the concentration of shikimic acid in the leaves of transgenic cotton. The authors observed lower fresh matter of seedlings in these cultivars, just as noted in the RR cotton crop when subjected to glyphosate. In our case, we also observed the increase in the concentrations of shikimic acid with glyphosate application, however was not different than conventional cultivar. Thus, the accumulation of shikimic acid may be a parameter which indicates the efficiency of the application and also of the glyphosate uptake by the plants (Velini et al. 2008).

\section{Conclusions}

The inclusion of the glyphosate resistance gene does not inhibit cotton development, while the application of the herbicide affects the Mn translocation of, plant biomass, and the leaf area of the cotton plant, possibly due to the toxicity caused by the metabolite formed during degradation of the herbicide.

Mn applications do not compensate for the negative effects on the production of DMW of the cotton plant.

The transgenic cultivar accumulates a high shikimic acid content, especially when subjected to the application of glyphosate.

\section{ORCID}

João Paulo Gonsiorkiewicz Rigon (D) http://orcid.org/0000-0003-0184-7898

Silvia Capuani (D) http://orcid.org/0000-0003-3645-3397

\section{References}

Andrade, G. J. M., and C. A. Rosolem. 2011. Uptake of manganese in RR soybean under glyphosate application. Revista Brasileira De Ciencia Do Solo 35:961-68. doi:10.1590/S0100-06832011000300030.

Basso, C. J., A. L. Santi, F. P. Lamego, and E. Girotto. 2011. Foliar application of manganese in transgenic soybean tolerant to glyphosate. Ciencia Rural 41:1726-31. doi:10.1590/S0103-84782011001000008.

Bott, S., T. Tesfamariam, H. Candan, I. Cakmak, V. Romheld, and G. Neumann. 2008. Glyphosate induced impairment of plant growth and micronutrient status in glyphosate- resistant soybean (Glycine max L.). Plant and Soil 312:185-94. doi:10.1007/s11104-008-9760-8.

Cakmak, I., A. Yazici, Y. Tutus, and L. Ozturk. 2009. Glyphosate reduced seed and leaf concentrations of calcium, manganese, magnesium, and iron in non-glyphosate resistant soybean. European Journal of Agronomy 31:114-19. doi:10.1016/j.eja.2009.07.001.

Duke, S. O., J. Lydon, W. C. Koskinen, T. B. Moorman, R. L. Chaney, and R. Hammerschmidt. 2012. Glyphosate effects on plant mineral nutrition, crop rhizosphere microbiota, and plant disease in glyphosate-resistant crops. Journal of Agricultural and Food Chemistry 60:10375-97. doi:10.1021/jf302436u.

Eker, S., L. Ozturk, A. Yazici, B. Erenoglu, V. Romheld, and I. Cakmak. 2006. Foliar-applied glyphosate substantially reduced uptake and transport of iron and manganese in sunflower (Helianthus annuus L.) plants. Journal of Agricultural and Food Chemistry 54:10019-25. doi:10.1021/jf0625196.

Fao. 1997. Food and agriculture organization of the United Nations 1997. Pesticide residues in food - 1997. Plant Production and Protection Paper series 145. 359p. Geneva World Health Organization, Lyon.

Fao. 2005. Food and agriculture organization of the United Nations. 2005. Pesticide residues in food. Plant Production and Protection Paper series 183. 337p. Geneva World Health Organization, Rome.

Feng, P. C. C., T. Chiu, and R. D. Sammons. 2003. Glyphosate efficacy is contributed by its tissue concentration and sensitivity in velvetleaf (Abutilon theophrasti). Pesticide Biochemistry and Physiology 77:83-91. doi:10.1016/j. pestbp.2003.08.005.

Gordon, B. 2007. Manganese nutrition of glyphosate-resistant and conventional soybeans. Better Crops 91:12-13.

Hoagland, D. R., and D. I. Arnon. 1950. The water-culture method for growing plants without soil, 32. Berkeley, CA: College of Agriculture, University of California. 
Johal, G. S., and D. M. Huber. 2009. Glyphosate effects on diseases of plants. European Journal of Agronomy 31:14452. doi:10.1016/j.eja.2009.04.004.

Marur, C. J., and O. Ruano. 2001. A reference system for determination of cotton plant development. Revista De Oleaginosas E Fibrosas 5:243-47.

Matallo, M. B., S. D. B. Almeida, A. L. Cerdeira, D. A. Franco, F. M. G. Blanco, P. T. C. Menezes, L. C. Luchini, M. A. M. Moura, and S. O. Duke. 2009. Microwave-assisted solvent extraction and analysis of shikimic acid from plant tissues. Planta Daninha 27:987-94. doi:10.1590/S0100-83582009000500012.

Nandula, V. K., K. N. Reddy, A. M. Rimando, S. O. Duke, and D. Poston. 2007. Glyphosate resistant and susceptible soybean (Glycine max) and canola (Brassica napus) dose response and metabolism relationships with Glyphosate. Journal of Agricultural and Food Chemistry 55:3540-45. doi:10.1021/jf0635681.

Neumann, G., S. Kohls, E. Landsberg, K. Stock-Oliveira, T. Yamada, and V. Römheld. 2006. Relevance of glyphosate transfer to non-target plants via rhizosphere. Journal of Plant Diseases and Protection 118:936-69.

Ozturk, L., A. Yazici, S. Eker, O. Gokmen, V. Roemheld, and I. Cakmak. 2008. Glyphosate inhibition of ferric reductase activity in iron deficient sunflower roots. New Phytologist 17:899-906. doi:10.1111/j.14698137.2007.02340.x.

Petersen, I. L., H. C. B. Hansen, H. W. Ravn, J. C. Sorensen, and H. Sorensen. 2007. Metabolic effects in rapeseed (Brassica napus L.) seedlings after root exposure to glyphosate. Pesticide Biochemistry and Physiology 89:220-29. doi:10.1016/j.pestbp.2007.06.009.

Pline, W. A., J. ;. W. Wilcut, S. O. Duke, K. L. Edmisten, and R. Wellz. 2002. Accumulation of shikimic acid in response to glyphosate applications in glyphosate-resistant and conventional cotton (Gossypium hirsutum L.). Journal of Agricultural and Food Chemistry 50:506-12. doi:10.1021/jf0110699.

Reddy, K. N., N. Bellaloui, and R. M. Zablotowicz. 2010. Glyphosate effect on shikimate, nitrate reductase activity, yield, and seed composition in corn. Journal of Agricultural and Food Chemistry 58:3646-50. doi:10.1021/jf904121y.

Reddy, K. N., A. M. Rimando, and S. O. Duke. 2004. Aminome-thylphosphonic acid, a metabolite of glyphosate, causes injury in glyphosate treated, glyphosate-resistant soybean. Journal of Agricultural and Food Chemistry 52:5139-43. doi:10.1021/jf049605v.

Römheld, V., G. Guldner, T. Yamada, L. Ozturk, I. Cakmak, and G. Neumann. 2005. Relevance of glyphosate in the rhizosphere of non-target plants in orchards for plant health. In Plant nutrition for food security, human health and environment protection, eds. C. J. Li, F. S. Zhang, A. Dobermann, P. Hinsinger, H. Lambers, X. L. Ly, P. Marschner, L. Maene, S. McGrath, O. Oenema, S. B. Peng, Z. Rengel, Q. R. Sen, R. Welch, N. Wiren, X. L. Yan, and Y. G. Zhu, 476-77. Beijing: Tsinghua University Press.

Rosolem, C. A., and L. Ferelli. 2000. Differential response of cotton cultivars to manganese in nutrient solution. Revista Brasileira De Ciencia Do Solo 24:355-61. doi:10.1590/S0100-06832000000200013.

Shieh, W. J., D. R. Geiger, and J. C. Serviates. 1991. Effect of N-(Phosphonomethyl) glycine on carbon assimilation and metabolism during a simulated natural day. Plant Physiology 97:1109-14.

Velini, E. D., E. Alves, M. C. Godoy, D. K. Meschede, R. T. Souza, and S. Duke. 2008. Glyphosate applied at low doses can stimulate plant growth. Pest Management Science 64:489-96.

Zablotowicz, R. M., and K. N. Reddy. 2007. Nitrogenase activity, nitrogen content, and yield responses to glyphosate in glyphosate-resistant soybean. Crop Protection 26:370-76. doi:10.1016/j.cropro.2005.05.013.

Zobiole, L. H. S., R. J. Kremer, R. S. Oliveira Junior, and J. Constantin. 2010b. Glyphosate affects photosynthesis in first and second generation of glyphosate-resistant soybeans. Plant and Soil 336:251-65. doi:10.1007/s11104-010-0474-3.

Zobiole, L. H. S., J. R. Oliveira, D. M. Huber, J. Constantin, C. Castro, F. A. Oliveira, and R. A. Oliveira Júnior. 2010 a. Glyphosate reduces shoot concentrations of mineral nutrients in glyphosate-resistant soybeans. Plant and Soil 328:57-69. doi:10.1007/s11104-009-0081-3. 